\title{
Spatio-Temporal Variations in Carbon Monoxide and Carbon Dioxide Levels in Three Motor Parks in Ibadan, Nigeria
}

\author{
Godson Rowland Ana, Olusola Olabisi Ogunseye \\ Department of Environmental Health Sciences, Faculty of Public Health, College of Medicine, University of Ibadan, Ibadan, Nigeria
}

Email address:

sholybliss4eva@gmail.com (O. O. Ogunseye)

\section{To cite this article:}

Godson Rowland Ana, Olusola Olabisi Ogunseye. Spatio-Temporal Variations in Carbon Monoxide and Carbon Dioxide Levels in Three Motor Parks in Ibadan, Nigeria. International Journal of Environmental Monitoring and Analysis. Vol. 3, No. 6, 2015, pp. 411-419. doi: 10.11648/j.ijema.20150306.15

\begin{abstract}
Carbon monoxide $(\mathrm{CO})$ and carbon dioxide $\left(\mathrm{CO}_{2}\right)$ emissions arising from vehicles and combustion processes in motor parks predisposes to adverse health outcomes and associated health risks. There is dearth of studies and data on air quality in motor parks in Nigeria, hence, the need to assess the levels of $\mathrm{CO}$ and $\mathrm{CO}_{2}$ and their relationship with meteorological parameters in three major motor parks in Ibadan, Nigeria. A cross-sectional comparative design was adopted for this study. Akinyele Motor Park (AMP) in Akinyele Local Government Area (LGA), Iwo Road Motor Park (IMP) in Ibadan North East LGA and New Garage Motor Park (NMP) in Ibadan South West LGA were purposively selected and levels of CO and CO were monitored for 2 months with appropriate gas meters, meteorological parameters were also monitored using Ventus W155 wireless weather station. Values obtained were compared with WHO and ASHRAE guideline limits. Descriptive and inferential statistics were used for data analysis at $\mathrm{p}=0.05$. CO concentrations (ppm) for AMP, IMP and NMP ranged from 2.0106.0, $2.0-83.0$ and $2.0-90.0$ respectively while the mean $\mathrm{CO}_{2}$ concentrations (ppm) were $395.4 \pm 30.5,356.3 \pm 57.1$ and $388.1 \pm 42.1$ respectively. There was a significant positive correlation between $\mathrm{CO}$ and $\mathrm{CO}_{2}(\mathrm{r}=0.258, \mathrm{p}=0.000)$ and also with four meteorological parameters; temperature $(\mathrm{r}=0.164)$, rainfall $(\mathrm{r}=0.105)$, heat index $(\mathrm{r}=0.134)$ and dew point $(\mathrm{r}=0.127)$ $(\mathrm{p}<0.05)$. A positive correlation was also found between $\mathrm{CO}_{2}$ and four meteorological parameters; temperature $(\mathrm{r}=0.276$, $\mathrm{p}=0.000)$, rainfall $(\mathrm{r}=0.125)$, heat index $(\mathrm{r}=0.232, \mathrm{p}=0.003)$ and dew point $(\mathrm{r}=0.028)$. For the three motor parks, CO concentrations (ppm) were $80 \%$ higher than WHO guideline of 9 ppm for 8 hour monitoring. Mean $\mathrm{CO}_{2}$ concentrations (ppm) were within ASHRAE guideline limit of $400 \mathrm{ppm}$. The study showed that meteorology has influence on $\mathrm{CO}$ and $\mathrm{CO}_{2}$ concentrations and motor park users are exposed to high levels of $\mathrm{CO}$. Routine monitoring of $\mathrm{CO}$ and $\mathrm{CO}_{2}$ is recommended in order to ensure these emissions do not exceed guideline limits.
\end{abstract}

Keywords: Vehicles, Emissions, Meteorology, Motor Parks, Routine Monitoring

\section{Introduction}

The global vehicular fleet has increased ten-fold over the last 40 years, and it is predicted to increase even more over the next three decades. The United Nations estimated that more than 600 million people living in cities and towns all over the world are exposed to unhealthy and dangerous levels of air pollutants generated by vehicles [1]. Vehicular emissions account for $51 \%$ of carbon monoxide, $34 \%$ of nitrogen oxides and $10 \%$ of particulate matter released each year in the United States [2].

Carbon monoxide (CO) is a colourless, odourless, non- irritating gas produced as a byproduct of incomplete combustion of carbonaceous materials. These materials include petroleum products, coal, natural gas, wood, and plastics. $\mathrm{CO}$ can be produced at toxic levels by internal combustion engines, structural fires, industrial operations, and improperly vented heating or cooking appliances [3]. Most of CO emissions (95 - 98\%) in a region can be related to anthropogenic activities [4].

When inhaled, CO binds to haemoglobin in red blood cells passing through the lungs, forming carboxyhemoglobin $(\mathrm{COHb})$. Because $\mathrm{CO}$ binds to haemoglobin more tightly than oxygen does, $\mathrm{CO}$ occupies the sites normally used to bind and carry oxygen from the lungs to the tissues. One mechanism of 
$\mathrm{CO}$ toxicity is that it decreases the oxygen content of arterial blood which reduces peripheral oxygen delivery [5].

Carbon dioxide $\left(\mathrm{CO}_{2}\right)$ is a dominant greenhouse gas [6]. Elevated levels of $\mathrm{CO}_{2}$ in the atmosphere and its relationship with global climate change have attracted interests from scientific communities, becoming a topical issue posing both political and economic challenges worldwide [7]. $\mathrm{CO}_{2}$ has drawn global attention due to its impact in terms of global warming as combustion of fuels in the power, transport and household sectors produce $\mathrm{CO}_{2}$ and a wide range of shortlived air pollutants constituting directly or indirectly a substantial proportion of climate change and the bulk of adverse effects on human health from global energy use [8].

Road transportation is the second biggest source of greenhouse gas emissions in countries of the European Union (EU) where it contributes about one-fifth of the EU's total emission of $\mathrm{CO}_{2}$ while passenger cars are responsible for $12 \%$ of EU's $\mathrm{CO}_{2}$ emissions [9]. The most recent energy use and emission inventories indicate that China surpassed the United States as the world's largest carbon emitter in 2006 [10]. Most of the assessments carried out on anthropogenic $\mathrm{CO}_{2}$ emissions were done in developed countries and emerging economies in Asia, which cumulatively account for $80 \%$ of $\mathrm{CO}_{2}$ emissions [11]. Africa also contributed to emission levels as fossil fuel emissions for Africa were $285 \mathrm{Tg} \mathrm{C}$ (teragrams of carbon) accounting for $3.7 \%$ of the global emissions in 2005 , however, fossil fuel emissions per capita in Africa are among the lowest in the world. Emissions from traffic are significant sources of air pollutants, especially in densely populated areas. $\mathrm{CO}_{2}$ is the main product of fuel burning, but a wide range of other gases are emitted concurrently [12].

The weather of a place represents the state of the atmosphere over a brief period of time [13]. The weather conditions of any given location is often described in terms of meteorological elements which include the state of the sky, temperature, winds, pressure, precipitation, and humidity. These factors initiate and influence atmospheric processes [14]. The atmosphere is affected by direct and indirect energy releases via human activities such as burning of fossil fuel, industrial emissions and other phenomenon like El Nino and La-Nina [15]. It is believed that synoptic weather is an important driver of air pollution episodes via certain physical and chemical processes such as turbulent mixing, long-range transport, photochemical production and deposition [16-18]. Data are available on the influence of air pollutants on regional and global climate but very few studies have assessed the impact of air pollutants to every day weather [19].

The importance of transportation cannot be overemphasized as it is responsible for the movement of people in and around the city and it is also vital to the survival of such cities [20]. Motor parks are widespread and common public spaces in urban areas in Nigeria because many people use public transport systems, however, they differ in design, nature and services [21]. The goal of establishing of motor parks is to provide satisfaction to its users and commuters [21-22]. Several motor parks in developing countries are in deplorable state and their settings are not consistent with standards and best practices, hence incapable of delivering comfort and serenity to users [21]. Motor parks in Nigeria are public areas where various activities take place. In addition to vehicular emissions, there are other sources of emission in motor parks that release $\mathrm{CO}$, $\mathrm{CO}_{2}$ and other gases into the motor park ambient environment. Hence, this study was carried out to assess the levels of $\mathrm{CO}$ and $\mathrm{CO}_{2}$ and their relationship with meteorological parameters in three major motor parks in Ibadan, Nigeria.

\section{Materials and Methods}

\subsection{Study Area}

The study area was Ibadan. Ibadan is the capital of Oyo State, one of the thirty six states in Nigeria. Strategically, positioned on longitude $3^{\circ} 53^{\prime}$ east of Greenwich Meridian and latitude $7^{\circ} 23^{\prime}$ north of the equator, this ancient city is located near the forest grassland boundary of south western Nigeria. The distance from Lagos is about $145 \mathrm{~km}$ North East [23]. As described by [24], Ibadan is situated close to the boundary between forest and grassland, which makes it a meeting point for people and products of both the forests and grassland areas.

This research was carried out in three major motor parks in Ibadan: Akinyele Motor Park (AMP) in Akinyele Local Government Area (LGA); Iwo Road Motor Park (IMP) in Ibadan North East LGA and the 'New Garage' Motor Park (NMP) located in the Ibadan South West LGA, within Ibadan municipal area. AMP caters for transport linking northern region which includes Kaduna, Abuja, Kano and other major cities. IMP caters for transport needs of passengers going towards eastern region comprising Benin, Warri, Port Harcourt, Uyo, Calabar and others. NMP links other major cities in the south west which includes Lagos, Abeokuta, Epe, Ijebu- Ode, and other coastal towns. These study sites were chosen purposively as they are the major exit points to reach northern, eastern and other western parts of the country. Many transportation devices such as taxis, minibuses and buses originate and terminate at these points [25].

\subsection{Description of Sampling Points}

Garmin GPS 60 was used to capture co-ordinates and elevation of three points in each motor park where monitoring of $\mathrm{CO}$ and $\mathrm{CO}_{2}$ were done. Table 1 shows the sampling points in the motor parks and their corresponding co-ordinates and elevation.

Table 1. Co-ordinates and elevation of sampling points at the motor parks.

\begin{tabular}{|c|c|c|c|c|}
\hline & Sampling points & Longitude & Latitude & Elevation \\
\hline \multirow{3}{*}{$\begin{array}{l}\text { AMP, } \\
\text { Ojoo }\end{array}$} & Point 1 & N07.46704 & E003.91339 & $243 \mathrm{~m}$ \\
\hline & Point 2 & N07.46731 ${ }^{\circ}$ & E003.91332 ${ }^{\circ}$ & $229 m$ \\
\hline & Point 3 & N07.46757 & E003.91288 & $231 \mathrm{~m}$ \\
\hline IMP, & Point 1 & N07.40205 & E003.94246 & $239 \mathrm{~m}$ \\
\hline Iwo & Point 2 & N07.40185 & E003.94242 ${ }^{\circ}$ & $213 \mathrm{~m}$ \\
\hline road & Point 3 & N07.40152 ${ }^{\circ}$ & E003.94212 & $230 \mathrm{~m}$ \\
\hline \multirow{3}{*}{$\begin{array}{l}\text { NMP, } \\
\text { Apata }\end{array}$} & Point 1 & N07.39480 & E003.81088 & $213 \mathrm{~m}$ \\
\hline & Point 2 & N07.39448 & $\mathrm{E} 003.81087^{\circ}$ & $180 \mathrm{~m}$ \\
\hline & Point 3 & N07.39436 ${ }^{\circ}$ & E003.81103ㅇ & $175 \mathrm{~m}$ \\
\hline
\end{tabular}




\subsection{Data Collection}

CO monitoring was done using Extech $\mathrm{CO} 10$ meter. 8hour $\mathrm{CO}$ measurement was taken in each motor park twice a week for two months (August and September, 2014). The measurements were taken at 1hour intervals in three strategic points (front, back and centre) in order to obtain the average $\mathrm{CO}$ measurement from 8am-4pm. $\mathrm{CO}_{2}$ monitoring was done using Telaire 7001 carbon dioxide and temperature monitor at the motor parks. 8-hour $\mathrm{CO}_{2}$ measurement was taken in each motor park twice a week for two months (August and September, 2014). The measurements were taken at 1hour intervals in three strategic points (front, back and centre) in order to obtain the average $\mathrm{CO}_{2}$ measurement from $8 \mathrm{am}-4 \mathrm{pm}$. Meteorological parameters such as temperature, humidity, rainfall, heat index, dew point and sea level pressure were monitored using Ventus W155 wireless weather station. 8hour monitoring of weather parameters was done twice a week in each motor park for 2 months (August and September, 2014) from $8 \mathrm{am}-4 \mathrm{pm}$ at 1 hour interval.

\subsection{Data Management and Statistical Analysis}

Data was entered and analysed using statistical package for the social sciences (SPSS) version 20. Descriptive and inferential statistics were used in this study. Descriptive statistics was used to summarize data. Mean \pm Standard Deviation (SD) and range was calculated for CO levels of the motor parks and compared with WHO guideline of 9ppm for 8 -hour monitoring [26]. Mean $\pm \mathrm{SD}$ and range was also calculated for $\mathrm{CO}_{2}$ levels of the motor parks and compared with ASHRAE guideline of $400 \mathrm{ppm}$ [27]. Mean \pm Standard Deviation (SD) and range was calculated for meteorological parameters such as temperature, humidity, rainfall, heat index, dew point and sea level pressure. ANOVA was used to test for any significant differences in the levels of $\mathrm{CO}$ and $\mathrm{CO}_{2}$ recorded at the motor parks. Pearson correlation test was carried out to check for relationships between $\mathrm{CO}, \mathrm{CO}_{2}$ and the meteorological parameters.

\section{Results}

\subsection{Mean CO Concentration at the Sampling Points}

Table 2 shows the mean $\mathrm{CO}$ concentration (ppm) of sampling points for morning and afternoon at the motor parks. Generally, afternoon mean CO concentrations were higher than morning. At AMP, Ojoo, for morning and afternoon, sampling point 3 recorded the highest concentration $(15.4 \pm 7.5$ and $19.5 \pm 10.9)$ while sampling point 2 recorded the lowest $(11.7 \pm 2.7$ and $13.8 \pm 6.6)$ respectively.

At IMP, Iwo road, during the morning period, sampling point 3 recorded the highest value $(15.1 \pm 8.3)$ while sampling point 2 recorded the lowest $(12.0 \pm 5.2)$. During the afternoon period, sampling point 1 recorded the highest concentration $(24.0 \pm 16.0)$ while sampling point 2 recorded the lowest (16.2 \pm 11.1$)$. At NMP, Apata, during the morning period, sampling point 3 recorded the highest concentration $(15.5 \pm 8.0)$ while sampling point 2 recorded the lowest $(9.74$ $\pm 3.13)$. During the afternoon period, sampling point 1 recorded the highest concentration $(26.3 \pm 16.9)$ while sampling point 2 recorded the lowest $(9.6 \pm 3.5)$.

For the three motor parks, sampling point 3 at NMP, Apata recorded the highest concentration $(15.5 \pm 8.0)$ for morning while sampling point 2 at NMP, Apata recorded the lowest $(9.7 \pm 3.1)$. For afternoon, sampling point 1 at NMP, Apata recorded the highest concentration $(26.3 \pm 16.9)$ while sampling point 2 at NMP, Apata recorded the lowest $(9.6 \pm$ 3.5). All the mean concentrations were higher than WHO guideline of $9 \mathrm{ppm}$.

\subsection{Mean $\mathrm{CO}_{2}$ Concentration at the Sampling Points}

Table 2 also shows the mean $\mathrm{CO}_{2}$ concentration (ppm) of sampling points for morning and afternoon at the motor parks. Generally, afternoon mean $\mathrm{CO}_{2}$ concentrations were higher than morning. At AMP, Ojoo, during the morning and afternoon periods, sampling point 3 recorded the highest concentration (397.7 \pm 38.9 and $410.9 \pm 17.4)$ while sampling point 2 recorded the lowest $(371.4 \pm 37.4$ and 396.0 $\pm 24.0)$ respectively.

At IMP, Iwo road, during the morning and afternoon periods, sampling point 1 recorded the highest concentration (361.4 \pm 61.0 and $407.9 \pm 47.6)$ while sampling point 2 recorded the lowest $(327.7 \pm 46.9$ and $350.0 \pm 51.6)$ respectively. At NMP, Apata, during the morning period, sampling point 3 recorded the highest concentration $(381.1 \pm 35.2)$ while sampling point 2 recorded the lowest $(365.3 \pm 26.6)$. During the afternoon period, sampling point 1 recorded the highest concentration $(419.9 \pm 44.4)$ while sampling point 2 recorded the lowest $(388.8 \pm 41.5)$.

For the three motor parks, sampling point 3 at AMP, Ojoo recorded the highest concentration (397.7 \pm 38.9) for morning while sampling point 2 at IMP, Iwo road recorded the lowest $(327.7 \pm 46.9)$. During afternoon period, sampling point 1 at NMP, Apata recorded the highest concentration (419.9 \pm 44.4$)$ while sampling point 2 at IMP, Iwo road recorded the lowest $(350.0 \pm 51.6)$.

\subsection{Temporal Variations in the Levels of CO}

Fig. 1 shows the pattern of $\mathrm{CO}$ levels during the 8 hours of monitoring. For AMP, Ojoo, the chart shows that CO concentration $(\mathrm{ppm})$ was lowest at $8 \mathrm{am}(11.3 \pm 4.2)$ and highest at 12noon (17.2 \pm 17.2). At IMP, Ojoo, CO concentration (ppm) was lowest at 8am (10.5 \pm 3.1$)$ and highest at $1 \mathrm{pm}(21.5 \pm 15.0)$. At NMP, Apata, CO concentration (ppm) was lowest at 8am $(9.4 \pm 2.9)$ and highest at $4 \mathrm{pm}(19.3 \pm 17.2)$. There was a statistically significant difference in the levels of $\mathrm{CO}$ across the 8 hours 
of monitoring at the three motor parks $(\mathrm{p}<0.05)$.

Table 2. $\mathrm{CO}$ and $\mathrm{CO}_{2}$ mean $\pm S D$ of the sampling points for morning and afternoon for the motor parks.

\begin{tabular}{|c|c|c|c|c|c|c|}
\hline \multicolumn{7}{|c|}{ AMP, Ojoo } \\
\hline & Point 1 & & Point 2 & & Point 3 & \\
\hline & Morning & Afternoon & Morning & Afternoon & Morning & Afternoon \\
\hline $\mathrm{CO}$ & $13.2 \pm 13.4$ & $14.0 \pm 9.5$ & $11.7 \pm 2.7$ & $13.8 \pm 6.6$ & $15.4 \pm 7.4$ & $19.5 \pm 11.0$ \\
\hline $\mathrm{CO}_{2}$ & $396.4 \pm 22.9$ & $404.9 \pm 13.5$ & $371.4 \pm 37.4$ & $396.0 \pm 24.0$ & $397.7 \pm 38.9$ & $410.9 \pm 17.4$ \\
\hline \multicolumn{7}{|c|}{ IMP, Iwo Road } \\
\hline & Point 1 & & Point 2 & & Point 3 & \\
\hline $\mathrm{CO}$ & $14.8 \pm 7.0$ & $24.0 \pm 16.0$ & $12.0 \pm 5.2$ & $16.2 \pm 11.1$ & $15.1 \pm 8.3$ & $18.7 \pm 13.1$ \\
\hline $\mathrm{CO}_{2}$ & $361.4 \pm 61.0$ & $407.9 \pm 47.6$ & $327.7 \pm 46.9$ & $350.0 \pm 51.6$ & $338.5 \pm 58.9$ & $362.3 \pm 41.4$ \\
\hline \multicolumn{7}{|c|}{ NMP, Apata } \\
\hline & Point 1 & & Point 2 & & Point 3 & \\
\hline & Morning & Afternoon & Morning & Afternoon & Morning & Afternoon \\
\hline $\mathrm{CO}$ & $14.7 \pm 9.3$ & $26.3 \pm 16.9$ & $9.7 \pm 3.1$ & $9.6 \pm 3.5$ & $15.5 \pm 8.0$ & $14.8 \pm 5.0$ \\
\hline $\mathrm{CO}_{2}$ & $380.0 \pm 44.0$ & $419.9 \pm 44.4$ & $365.3 \pm 26.6$ & $388.8 \pm 41.5$ & $381.1 \pm 35.2$ & $402.8 \pm 41.4$ \\
\hline
\end{tabular}

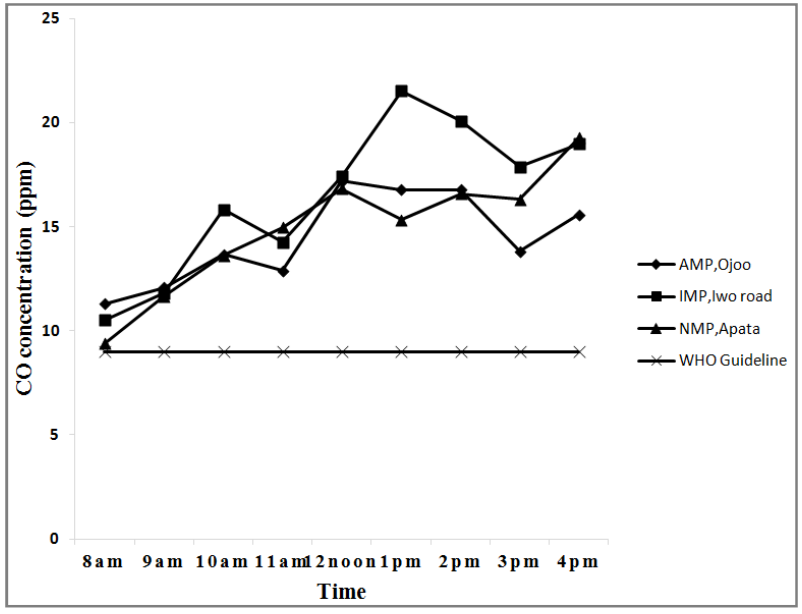

Figure 1. Concentration of $\mathrm{CO}$ during the 8 hours of monitoring.

\subsection{Temporal Variations in the Levels of $\mathrm{CO}_{2}$}

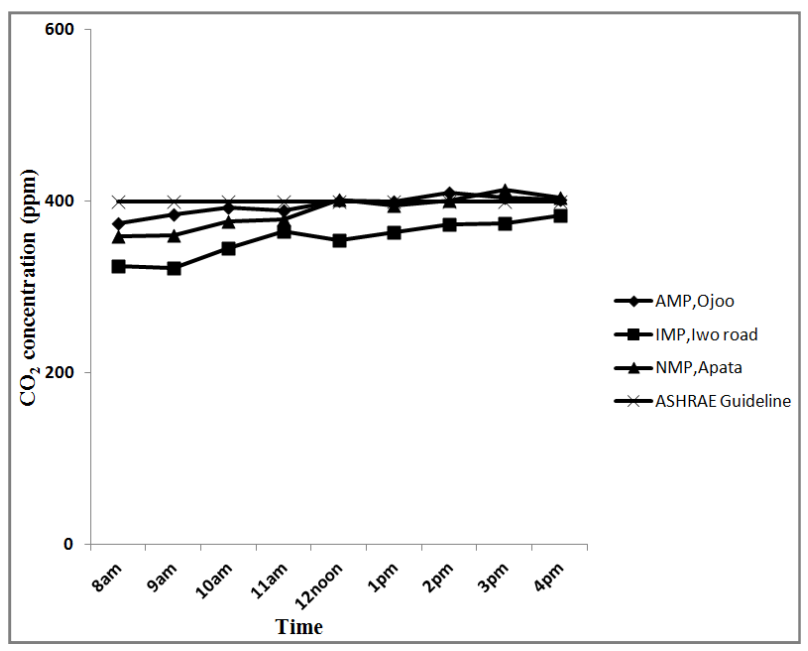

Figure 2. Concentration of $\mathrm{CO}_{2}$ during the 8 hours of monitoring.

Fig. 2 shows the pattern of $\mathrm{CO}_{2}$ levels during the 8 hours of monitoring. For AMP, Ojoo, the chart shows that $\mathrm{CO}_{2}$ concentration $(\mathrm{ppm})$ was lowest at $8 \mathrm{am}(374.6 \pm 37.2)$ and highest at $2 \mathrm{pm}(409.9 \pm 12.7)$. At IMP, Iwo road, $\mathrm{CO}_{2}$ concentration $(\mathrm{ppm})$ was lowest at 9am $(322.3 \pm 55.0)$ and highest at $4 \mathrm{pm}(383.5 \pm 52.2)$. At NMP, Apata, $\mathrm{CO}_{2}$ concentration $(\mathrm{ppm})$ was lowest at $8 \mathrm{am}(358.9 \pm 23.6)$ and highest at $3 \mathrm{pm}(413.9 \pm 55.9)$. There was a statistically significant difference in the levels of $\mathrm{CO}_{2}$ across the 8 hours of monitoring at the three motor parks $(\mathrm{p}<0.05)$.

\subsection{Spatial Variations in the Levels of $\mathrm{CO}$ and $\mathrm{CO}_{2}$}

Table 3 shows the comparison of mean concentrations of $\mathrm{CO}$ and $\mathrm{CO}_{2}$ at the three sampling points in each motor park, and the result of ANOVA shows that there were differences in the levels of $\mathrm{CO}$ and $\mathrm{CO}_{2}$ at the sampling points in each motor park and the differences were statistically significant. $(\mathrm{p}<0.05)$.

Table 3. Comparison of levels of $\mathrm{CO}$ and $\mathrm{CO}_{2}$ at sampling points of each motor park.

\begin{tabular}{llllll}
\hline & & Point 1 & Point 2 & Point 3 & p-value \\
\hline \multirow{4}{*}{ CO } & AMP, Ojoo & $13.6 \pm 11.8$ & $12.6 \pm 4.9$ & $17.2 \pm 1.4$ & 0.000 \\
& IMP, Iwo road & $18.9 \pm 12.6$ & $13.9 \pm 8.5$ & $16.7 \pm 10.8$ & 0.000 \\
& NMP, Apata & $19.9 \pm 14.4$ & $9.7 \pm 3.3$ & $15.2 \pm 6.8$ & 0.000 \\
& AMP, Ojoo & $400.2 \pm 19.6$ & $382.3 \pm 34.2$ & $403.6 \pm 31.7$ & 0.000 \\
$\mathrm{CO}_{2}$ & IMP, Iwo road & $382.1 \pm 59.7$ & $337.6+49.9$ & $349.1+52.8$ & 0.000 \\
& NMP, Apata & $397.7+48.1$ & $375.7+35.7$ & $390.8+39.3$ & 0.020 \\
\hline
\end{tabular}

\subsection{Mean and Range of $\mathrm{CO}$ and $\mathrm{CO}_{2}$ for the Motor Parks}

Table 4 shows the overall mean and range for $\mathrm{CO}$ and $\mathrm{CO}_{2}$ in the motor parks. The overall mean $\mathrm{CO}$ concentration (ppm) for AMP, Ojoo, IMP, Iwo road and NMP, Apata were $14.5 \pm 9.3,16.5 \pm 11.0$ and $14.9 \pm 10.2$ respectively $(\mathrm{p}=0.009)$ while the range were $2.0-106.0,2.0-83.0$ and 2.090.0 respectively. For AMP, Ojoo, IMP, Iwo road and NMP, Apata, CO (ppm) concentrations were $82 \%, 83 \%$ and $75 \%$ higher than WHO guideline of $9 \mathrm{ppm}$ for 8hour monitoring 
respectively. Generally, CO (ppm) concentrations were $80 \%$ higher than WHO guideline of 9 ppm for 8 hour monitoring across the motor parks.

Mean $\mathrm{CO}_{2}$ concentration (ppm) for AMP, Ojoo, IMP, Iwo road and NMP, Apata were $395.4 \pm 30.5,356.3 \pm 57.1$ and $388.1 \pm 42.1$ respectively $(\mathrm{p}=0.000)$ while the range were 290.0-450.0, 255.0-524.0 and 320.0-560.0 respectively. These mean $\mathrm{CO}_{2}$ concentrations are lower than ASHRAE guideline of $400 \mathrm{ppm}$.

Figures 3 and 4 show the mean $\pm \mathrm{SD}$ of $\mathrm{CO}$ and $\mathrm{CO}_{2}$ across the motor parks respectively.

Table 4. Mean and range of $\mathrm{CO}$ and $\mathrm{CO}_{2}$ for the motor parks.

\begin{tabular}{lllll}
\hline & AMP, Ojoo & $\begin{array}{l}\text { IMP, Iwo } \\
\text { road }\end{array}$ & NMP, Apata & p-value \\
\hline $\mathrm{CO}(\mathrm{ppm})$ & $14.5 \pm 9.3$ & $16.5 \pm 11.0$ & $14.9 \pm 10.2$ & 0.009 \\
& $2-106$ & $2-83$ & $2-90$ & \\
$\mathrm{CO}_{2}(\mathrm{ppm})$ & $395.4 \pm 30.5$ & $356.3 \pm 57.1$ & $388.1 \pm 42.1$ & 0.000 \\
& $290-450$ & $255-524$ & $320-560$ & \\
\hline
\end{tabular}

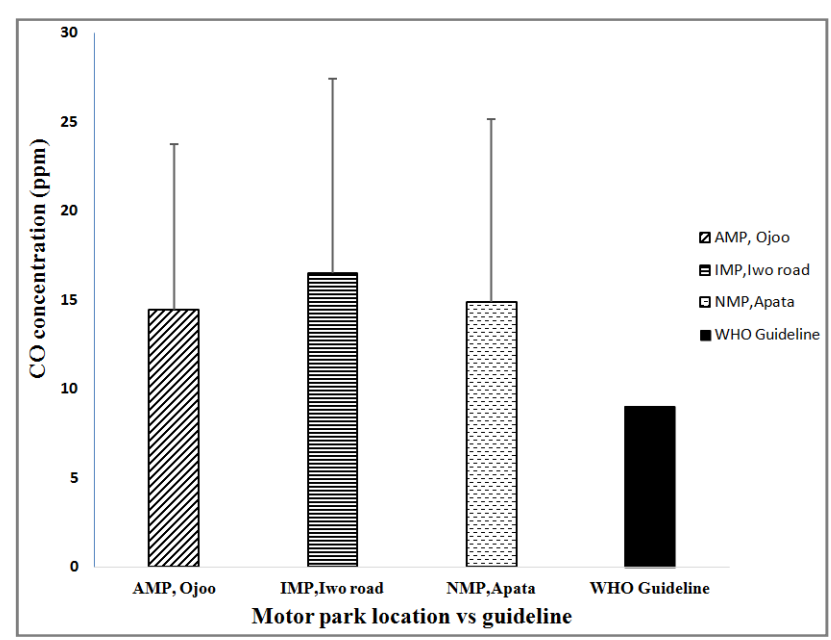

Figure 3. Mean CO concentrations across the motor parks compared with WHO guideline.

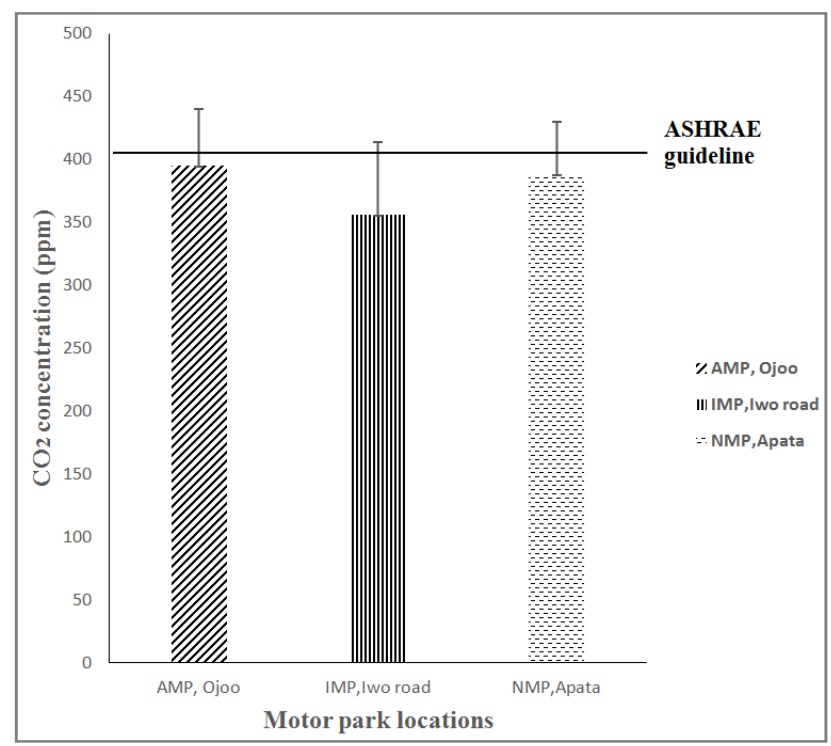

Figure 4. Mean $\mathrm{CO}_{2}$ concentrations across the motor parks compared with ASHRAE guideline.

\subsection{Meteorological Assessment}

Table 5 shows the mean $\pm \mathrm{SD}$ and range of meteorological parameters assessed at the motor parks. AMP, Ojoo recorded the highest mean temperature $(28.5 \pm 2.6)$ while IMP, Iwo road recorded the lowest $(28.4 \pm 2.0)$. NMP, Apata recorded the highest mean humidity $(82.0 \pm 9.3)$ while AMP, Ojoo recorded the lowest $(79.3 \pm 9.8)$. AMP, Ojoo recorded the highest mean rainfall $(278.0 \pm 404.8)$ while NMP, Apata recorded the lowest $(144.4 \pm 206.6)$. NMP, Apata recorded the highest mean heat index $(33.8 \pm 8.4)$ while IMP, Iwo road recorded the lowest $(32.9 \pm 4.1)$. NMP, Apata recorded the highest mean dew point $(25.1 \pm 1.5)$ while AMP, Ojoo recorded the lowest $(24.4 \pm 1.4)$. NMP, Apata recorded the highest mean sea level pressure $(1012.6 \pm 2.0)$ while IMP, Iwo road recorded the lowest $(1011.7 \pm 4.3)$.

Table 5. Mean and range of meteorological parameters for the motor parks.

\begin{tabular}{llll}
\hline & AMP, Ojoo & IMP, Iwo road & NMP, Apata \\
\hline Temperature $\left({ }^{\circ} \mathrm{C}\right)$ & $28.5 \pm 2.6$ & $28.4 \pm 2.0$ & $28.4 \pm 2.3$ \\
& $22.3-35.0$ & $25.2-33.3$ & $22.8-34.2$ \\
Humidity $(\%)$ & $79.3 \pm 9.8$ & $79.5 \pm 9.0$ & $82.0 \pm 9.3$ \\
& $54.0-95.0$ & $55.0-91.0$ & $55.0-96.0$ \\
Rainfall $(\mathrm{mm})$ & $278.0 \pm 404.8$ & $205.1 \pm 361.9$ & $144.4 \pm 206.6$ \\
& $0.0-2309.0$ & $0.0-2511.0$ & $0.0-997.7$ \\
Heat Index $\left({ }^{\circ} \mathrm{C}\right)$ & $32.9 \pm 5.5$ & $32.9 \pm 4.1$ & $33.8 \pm 8.4$ \\
& $19.8-54.9$ & $26.0-45.0$ & $22.8-47.2$ \\
Dew point $\left({ }^{\circ} \mathrm{C}\right)$ & $24.4 \pm 1.4$ & $24.5 \pm 1.3$ & $25.1 \pm 1.5$ \\
& $21.4-30.5$ & $22.3-28.0$ & $19.3-28.8$ \\
Sea level pressure & $1012.1 \pm 2.2$ & $1011.7 \pm 4.3$ & $1012.6 \pm 2.0$ \\
(hpa) & $1004.0-1018.0$ & $993.0-1017.0$ & $1005.0-1017.0$ \\
\hline
\end{tabular}

\subsection{Relationships Between $\mathrm{CO}, \mathrm{CO}_{2}$ and Meteorological Parameters}

Pearson correlation test was carried out between $\mathrm{CO}, \mathrm{CO}_{2}$ and the meteorological parameters as shown in Table 6. The table shows that there was a significant positive correlation between $\mathrm{CO}$ and $\mathrm{CO}_{2}(\mathrm{r}=0.258, \mathrm{p}=0.000)$. Fig. 5 shows the strength of the linear relationship between the levels of $\mathrm{CO}$ and $\mathrm{CO}_{2}\left(\mathrm{R}^{2}=6.7 \%\right)$. A significant positive correlation was also recorded between $\mathrm{CO}$ and four meteorological parameters namely; temperature $(\mathrm{r}=.0164)$, rainfall $(\mathrm{r}=$ $0.105)$, heat index $(r=0.134)$ and dew point $(r=0.127)$ $(\mathrm{p}<0.05)$ while there existed a negative correlation between $\mathrm{CO}$ and the remaining two meteorological parameters, i.e, humidity $(\mathrm{r}=-0.114, \mathrm{p}=0.018)$ and sea level pressure $(\mathrm{r}=$ 0.002).

A positive correlation was also found between $\mathrm{CO}_{2}$ and four meteorological parameters namely; temperature $(\mathrm{r}=$ $0.276, \mathrm{p}=0.000)$, rainfall $(\mathrm{r}=0.125)$, heat index $(\mathrm{r}=0.232$, $\mathrm{p}=0.003)$ and dew point $(\mathrm{r}=0.028)$ while a negative correlation was recorded between $\mathrm{CO}_{2}$ and the remaining two meteorological parameters i.e humidity $(\mathrm{r}=-0.286, \mathrm{p}=0.000)$ and sea level pressure $(r=-0.172, p=0.035)$. 
There existed a significant negative correlation between temperature and two other meteorological parameters namely humidity $(r=-0.795, p=0.000)$ and sea level pressure $(r=$ $0.230, \mathrm{p}=0.000$ ), while temperature correlated positively with rainfall $(r=0.155, p=0.001)$, heat index $(r=0.706, p=0.000)$ and dew point $(\mathrm{r}=0.413, \mathrm{p}=0.000)$.

There was a significant positive correlation between humidity and two other meteorological parameters, namely; dew point $(r=0.210, p=0.000)$ and sea level pressure $(r=0.219$, $\mathrm{p}=0.000$ ), while a significant negative correlation existed between humidity and heat index $(\mathrm{r}=-0.431, \mathrm{p}=0.000)$.

A significant positive correlation was observed between rainfall and two other meteorological parameters, namely; heat index $(\mathrm{r}=0.163, \mathrm{p}=0.001)$ and dew point $(\mathrm{r}=0.188$, $\mathrm{p}=0.000)$. A positive correlation existed between heat index and dew point $(\mathrm{r}=0.651, \mathrm{p}=0.000)$ while a negative correlation was noticed between heat index and sea level pressure $(r=-0.223, p=0.000)$.

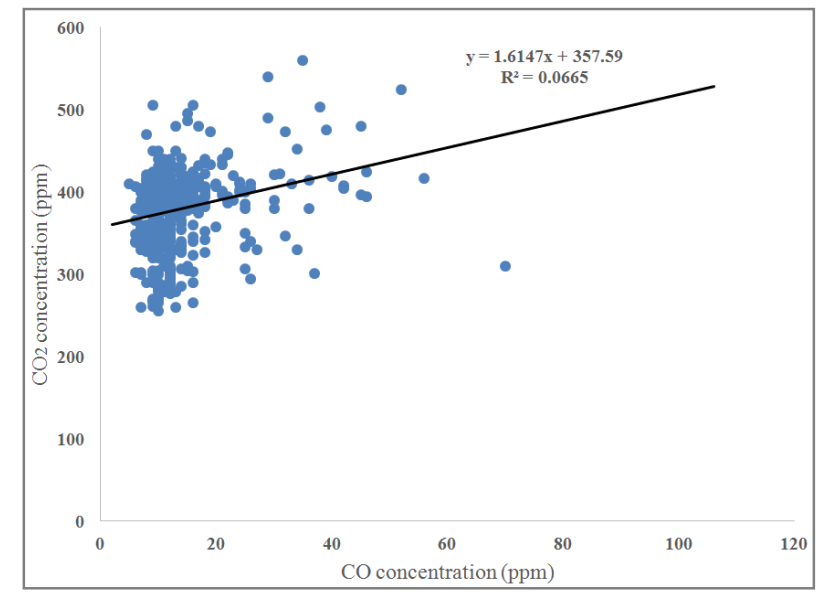

Figure 5. Relationship between levels of $\mathrm{CO}$ and $\mathrm{CO}_{2}$ at the motor parks.

Table 6. Correlation between $\mathrm{CO}, \mathrm{CO}_{2}$ and meteorological parameters.

\begin{tabular}{|c|c|c|c|c|c|c|c|c|}
\hline $\begin{array}{l}\text { Pearson Correlation } \\
\text { coefficient Sig ( } 2 \text { tailed) }\end{array}$ & $\mathrm{CO}(\mathrm{ppm})$ & $\mathrm{CO}_{2}(\mathrm{ppm})$ & $\begin{array}{l}\text { Temperature } \\
\left({ }^{\circ} \mathrm{C}\right)\end{array}$ & $\begin{array}{l}\text { Humidity } \\
(\%)\end{array}$ & $\begin{array}{l}\text { Rainfall } \\
(\mathrm{mm})\end{array}$ & $\begin{array}{l}\text { Heat } \\
\text { index }\left({ }^{\circ} \mathrm{C}\right)\end{array}$ & $\begin{array}{l}\text { Dew point } \\
\left({ }^{\circ} \mathrm{C}\right)\end{array}$ & $\begin{array}{l}\text { Sea level } \\
\text { pressure (hpa) }\end{array}$ \\
\hline $\mathrm{CO}(\mathrm{ppm})$ & 1 & & & & & & & \\
\hline $\mathrm{CO}_{2}(\mathrm{ppm})$ & $\begin{array}{l}0.258^{* *} \\
0.000\end{array}$ & 1 & & & & & & \\
\hline Temperature $\left({ }^{\circ} \mathrm{C}\right)$ & $\begin{array}{l}0.164^{* *} \\
0.001\end{array}$ & $\begin{array}{l}0.276^{* *} \\
0.000\end{array}$ & 1 & & & & & \\
\hline Humidity (\%) & $\begin{array}{l}-0.114^{*} \\
0.018\end{array}$ & $\begin{array}{l}-0.286^{* *} \\
0.000\end{array}$ & $\begin{array}{l}-0.795^{* *} \\
0.000\end{array}$ & 1 & & & & \\
\hline Rainfall (mm) & $\begin{array}{l}0.105^{*} \\
0.029\end{array}$ & $\begin{array}{l}0.125 \\
0.113\end{array}$ & $\begin{array}{l}0.155^{* *} \\
.155^{* *}\end{array}$ & $\begin{array}{l}-0.048 \\
0.319\end{array}$ & 1 & & & \\
\hline Heat index $\left({ }^{\circ} \mathrm{C}\right)$ & $\begin{array}{l}0.134^{* *} \\
0.005\end{array}$ & $\begin{array}{l}0.232^{* *} \\
0.003\end{array}$ & $\begin{array}{l}0.706^{* *} \\
0.000\end{array}$ & $\begin{array}{l}-0.431^{* *} \\
0.000\end{array}$ & $\begin{array}{l}0.163^{* *} \\
0.001\end{array}$ & 1 & & \\
\hline Dew point $\left({ }^{\circ} \mathrm{C}\right)$ & $\begin{array}{l}0.127^{* *} \\
0.010\end{array}$ & $\begin{array}{l}0.028 \\
0.735\end{array}$ & $\begin{array}{l}0.413^{* *} \\
0.000\end{array}$ & $\begin{array}{l}0.210^{* *} \\
0.000\end{array}$ & $\begin{array}{l}0.188^{* *} \\
0.000\end{array}$ & $\begin{array}{l}0.651^{* *} \\
0.000\end{array}$ & 1 & \\
\hline Sea level pressure (hpa) & $\begin{array}{l}-0.002 \\
0.970\end{array}$ & $\begin{array}{l}-0.172^{*} \\
0.035\end{array}$ & $\begin{array}{l}-0.230^{* *} \\
0.000\end{array}$ & $\begin{array}{l}0.219^{* *} \\
0.000\end{array}$ & $\begin{array}{l}-0.003 \\
0.945\end{array}$ & $\begin{array}{l}-0.223^{* *} \\
0.000\end{array}$ & $\begin{array}{r}-0.048 \\
0.346\end{array}$ & 1 \\
\hline
\end{tabular}

**. Correlation is significant at the 0.01 level (2-tailed)

*. Correlation is significant at the 0.05 level (2-tailed)

\section{Discussion}

Generally, afternoon mean CO concentrations were higher than morning. This may be due to increased influx of vehicles into the motor parks in the afternoon. This result is in line with the study by [28] in Enugu, Nigeria but at variance with studies by [29] in Lafia metropolis and [30] in Benin City where CO concentration was higher in the morning but lower in the afternoon.

There were variations in the mean $\mathrm{CO}$ concentration at the sampling points in the motor parks. This was due to the fact that, at each sampling point in the motor parks, activities that emit CO differ in degree and frequency. The pollution level at these sampling points varied as observed during $\mathrm{CO}$ monitoring in the motor parks and the difference in mean $\mathrm{CO}$ level across the sampling points was significant for the motor parks, hence, there were spatial variations in $\mathrm{CO}$ levels for the motor parks. The pattern of $\mathrm{CO}$ emissions during the 8 hours of monitoring revealed that there were temporal variations in $\mathrm{CO}$ concentrations across the three motor parks.
This result is supported by [31] who stated that ambient CO concentrations have daily and seasonal variations, as well as complex spatial distributions.

IMP, Iwo road recorded the highest mean $\mathrm{CO}$ concentration (ppm) (16.5 \pm 11.0$)$ while AMP, Ojoo recorded the lowest (14.5 \pm 9.3$)$. There was significant difference in the mean CO concentration of the motor parks $(\mathrm{p}=0.009)$, hence, the motor parks vary in $\mathrm{CO}$ levels. The highest mean $\mathrm{CO}$ concentration recorded at IMP, Iwo road may be attributed to high vehicular density in the motor park than others. According to a study by [32], mean CO concentration at Iwo road near overhead bridge was $86 \mathrm{ppm}$ while it was $32.5 \mathrm{ppm}$ at Ojoo trailer park. These mean $\mathrm{CO}$ concentrations were higher than the mean $\mathrm{CO}$ concentrations recorded in this study.

There were spatial and temporal variations in $\mathrm{CO}$ concentrations across the three motor parks and this is corroborated by the study by [30]. All the mean CO concentrations across sampling points, during the 8 hours of monitoring and overall mean for the motor parks were above the WHO guideline of 9 ppm [26]. 
The CO range (ppm) for AMP, Ojoo, IMP, Iwo road and NMP, Apata were 2.0-106.0, 2.0-83.0 and 2.0-90.0 respectively and generally, these $\mathrm{CO}$ concentrations (ppm) were $80 \%$ higher than WHO guideline of $9 \mathrm{ppm}$ for 8 hour monitoring across the motor parks. Hence, motor park traders are exposed to high concentration of $\mathrm{CO}$ in the motor parks. This finding is supported by a study that investigated the ambient carbon monoxide and carboxyhaemoglobin levels in Ibadan City, Nigeria by [33], it was reported that ambient carbon monoxide levels in Ibadan city were between 3.0 and $55.0 \mathrm{ppm}$ with a mean value and standard deviation of $20.12 \pm$ $1.40 \mathrm{ppm}$. The study indicated that Ibadan city dwellers were generally exposed to higher levels of $\mathrm{CO}$ than WHO permissible guideline limit. Vocations and occupations requiring workers to spend long periods on the highways are at higher risk of exposure. Potential exposures that exceed the existing guideline may be of greater concern to public health because they increase the total body burden for $\mathrm{CO}$ [34].

Generally, afternoon mean $\mathrm{CO}_{2}$ concentrations were higher than morning. This may also be due to increased influx of vehicles into the motor parks in the afternoon, and also increase in air pollution related activities in the motor parks. This could also be explained by stating that $\mathrm{CO}$ is co-emitted with $\mathrm{CO}_{2}$ from combustion sources [7], hence, increase in $\mathrm{CO}$ concentration in the afternoon when compared to morning will result in increased $\mathrm{CO}_{2}$ concentration in the afternoon as compared to morning.

There were variations in the mean $\mathrm{CO}_{2}$ concentration at the sampling points in the motor parks. This is due to the fact that at each sampling point in the motor parks, $\mathrm{CO}_{2}$ emitting activities vary. The emission levels at these sampling points differ as observed during $\mathrm{CO}_{2}$ monitoring in the motor parks and the difference in mean $\mathrm{CO}_{2}$ levels across the sampling points was statistically significant for the motor parks, hence a spatial variation in $\mathrm{CO}_{2}$ level was observed for the motor parks. The pattern of $\mathrm{CO}_{2}$ emission during the 8 hours of monitoring revealed that there were temporal variations in the $\mathrm{CO}_{2}$ concentration across the three motor parks.

AMP, Ojoo recorded the highest mean $\mathrm{CO}_{2}$ concentration (395.4 \pm 30.5$)$ while IMP, Iwo road recorded the lowest (356.3 \pm 57.1$)$. This result is similar to that reported in a study by [8] where the mean $\mathrm{CO}_{2}$ concentration in traffic area TA (TA comprised of Ojoo park, Mokola round about, Agbowo complex area, Challenge park and Oluyole Industrial area) was highest at $390 \pm 64 \mathrm{ppm}$ during the rainy season. However, the result of this study is lower than that reported by [35], in which $\mathrm{CO}_{2}$ concentration was as high as 1710 ppm at Kawo motor park in Kaduna.

There was significant difference in the mean $\mathrm{CO}_{2}$ concentration across the motor parks $(p=0.000)$, hence, the motor parks vary in $\mathrm{CO}_{2}$ concentrations. All the mean $\mathrm{CO}_{2}$ concentration of the motor parks are below ASHRAE guideline of $400 \mathrm{ppm}$ [27]. There was a significant positive correlation between $\mathrm{CO}$ and $\mathrm{CO}_{2} \quad(\mathrm{r}=0.258, \mathrm{p}=0.000$, $\mathrm{R}^{2}=6.7 \%$ ). $\mathrm{CO}$ is co-emitted with $\mathrm{CO}_{2}$ from combustion sources, leading to a significant positive correlation between them when combustion is a significant source of observed
$\mathrm{CO}_{2}$ [7]. There was a significant positive correlation between $\mathrm{CO}$ and temperature $(\mathrm{r}=0.164, \mathrm{p}=0.001)$. This could be attributed to the fact that internal combustion engines of vehicles perform better in cold temperature and emit less $\mathrm{CO}$ but as temperature increases, the engine efficiency reduces, hence, releasing more $\mathrm{CO}$ into the motor park ambient environment. A study by [36] at Gaza strip reported a positive correlation between outdoor $\mathrm{CO}$ and outdoor temperature during winter.

$\mathrm{CO}$ concentrations in the motor parks have significant relationships with meteorological parameters, hence, meteorology has influence on the levels of $\mathrm{CO}$ in the motor parks. This assertion is corroborated by [31] who noted that meteorological conditions highly influence $\mathrm{CO}$ levels in urban regions. There was also a significant positive correlation between $\mathrm{CO}_{2}$ and temperature. This is expected as $\mathrm{CO}$ is co-emitted with $\mathrm{CO}_{2}$ from combustion sources [7]. However, in a study by [37] in Poland, significant negative correlation was found between $\mathrm{CO}_{2}$ and air temperature. This is further corroborated by a study by [19] in Eastern China that showed that intense air pollution significantly affects local synoptic weather by influencing certain weather parameters indicating clear air pollution-weather interactions. Generally, for the motor parks, temporal variations were observed for all meteorological parameters and there were marked relationships between them.

\section{Conclusion and Recommendations}

This study assessed levels of $\mathrm{CO}$ and $\mathrm{CO}_{2}$ and their relationships with meteorological parameters in three major motor parks in Ibadan, Nigeria. Mean CO concentration for afternoon was higher than that of morning at the motor parks due to increased influx of vehicles into the motor parks in the afternoon, and also increase in air pollution related activities. There were temporal variations in $\mathrm{CO}$ concentration across the 8 hours of monitoring and spatial variations across the sampling points for the motor parks. IMP, Iwo road recorded the highest mean $\mathrm{CO}$ concentration while AMP, Ojoo recorded the lowest. Generally, CO (ppm) concentrations were $80 \%$ higher than WHO guideline of 9 ppm for 8 hour monitoring across the motor parks. Therefore, motor park users are exposed to high concentrations of $\mathrm{CO}$ and are susceptible to effects of $\mathrm{CO}$ exposure.

Mean $\mathrm{CO}_{2}$ concentration for afternoon was higher than that of morning at the motor parks due to increased influx of vehicles into the motor parks in the afternoon, and also increase in air pollution related activities. There were temporal variations in $\mathrm{CO}_{2}$ concentration across the 8 hours of monitoring and spatial variations across the sampling points for the motor parks. AMP, Ojoo recorded the highest mean $\mathrm{CO}_{2}$ concentration while IMP, Iwo road recorded the lowest. The mean $\mathrm{CO}_{2}$ concentrations for the motor parks were lower than ASHRAE guideline of $400 \mathrm{ppm}$.

There was a significant positive correlation between $\mathrm{CO}$ and $\mathrm{CO}_{2}$. Generally, $\mathrm{CO}$ and $\mathrm{CO}_{2}$ concentrations in the motor parks have significant relationships with the meteorological 
parameters, hence, meteorology has influence on the levels of $\mathrm{CO}$ and $\mathrm{CO}_{2}$ in the motor parks. Temporal variations were observed for all the meteorological parameters across the 8 hours of monitoring at the motor parks and there were marked relationships between them.

Fixed site $\mathrm{CO}$ and $\mathrm{CO}_{2}$ monitoring equipment should be installed at the motor parks to ensure regular assessment of these gases at the motor parks so that they do not exceed guideline limits.

\section{Acknowledgements}

The authors are grateful to staff and students in the Department of Environmental Health Sciences, Faculty of Public Health, College of Medicine, University of Ibadan, who contributed to the successful completion of this research. The technical support from concerned individuals within and outside the University is also gratefully acknowledged.

\section{References}

[1] Cacciola, R.R., Sarva, M., and Polosa, R. 2002. Adverse respiratory effects and allergic susceptibility in relation to particulate air pollution: flirting with disaster. Allergy 57:281286.

[2] Olamijulo, J. O. and Ana, G. R. E. E. 2013. Air Quality in Relation to Vehicular Traffic-Related Gaseous Emissions in two Selected Local Government Areas in South-Western Nigeria. International Journal of Environmental Monitoring and Analysis. Vol. 1, No. 4, 2013, pp. 121-127.doi: 10.11648/j.ijema.20130104.12.

[3] Centers for Disease Control and Prevention. 1997. Carbon Monoxide Intoxication and Death in a Newly Constructed Sewer Manhole. Hazard Evaluation and Technical Assistance Report HETA 98-0020. http://www.cdc.gov/niosh/hhe/.

[4] Boudaghpour, S. and Jadidi A. 2009. Investigation of the effect of outlet pollutants of cement production industries around Tehran and approaches to control and eliminate pollutants. International Journal of Physical Sciences 4:486495.

[5] Piantadosi, C.A. 2004. Carbon monoxide poisoning. Undersea and Hyperbaric Medicine Journal 31.1:167-177.

[6] Canadell, J. G., Raupach, M. R. and Houghton, R. A. 2009. Anthropogenic $\mathrm{CO}_{2}$ emissions in Africa. Biogeosciences, 6: 463-468.

[7] Wang, Y., Munger, J. W., Xu, S., McElroy, M. B., Hao, J., Nielsen, C. P., and Ma, H. et al. 2010. $\mathrm{CO}_{2}$ and its correlation with $\mathrm{CO}$ at a rural site near Beijing: Implications for combustion efficiency in China. Atmospheric Chemistry and Physics 10:8881-8897.

[8] Ana, G.R., Ojelabi, Peju and Shendell, Derek, G. 2014 Spatial-temporal variations in carbon dioxide levels in Ibadan, Nigeria. International Journal of Environmental Health $\begin{array}{ll}\text { Research 2014: } & \end{array}$ http://dx.doi.org/10.1080/09603123.2014.938024

[9] De Wilde, H.P.J. and Kroon, P. 2013. Policy options to reduce passenger cars emissions after 2020. Energy Research Centre of the Netherland, February, 2013.

[10] Gregg, J. S., Andres, R. J. and Marland, G. 2008. China: Emissions pattern of the world leader in $\mathrm{CO}_{2}$ emissions from fossil fuel consumption and cement production. Geophysical Research Letters 35:10.

[11] Raupach, M. R., Marland, G., Ciais, P., Le Quere, C., Canadell, J. G., Klepper, G., and Field, C. B. 2007. Global and regional drivers of accelerating $\mathrm{CO}_{2}$ emissions, Proceedings of the National Academy of Sciences, 0700609104.

[12] Popa, M.E., Vollmer, M. K., Jordan, A., Brand, W. A., Pathirana, S. L., Rothe, M., and Röckmann, T. 2014. Vehicle emissions of greenhouse gases and related tracers from a tunnel study: $\mathrm{CO}: \mathrm{CO}_{2}, \mathrm{~N}_{2} \mathrm{O}: \mathrm{CO}_{2}, \mathrm{CH}_{4}: \mathrm{CO}_{2}, \mathrm{O}_{2}: \mathrm{CO}_{2}$ ratios, and the stable isotopes ${ }^{13} \mathrm{C}$ and ${ }^{18} \mathrm{O}$ in $\mathrm{CO}_{2}$ and $\mathrm{CO}$. Atmospheric Chemistry and Physics, 14, 2105-2123.

[13] Aiyelabegan, A. T. 2014. Latitudinal dependence of some meteorological parameters in Nigeria. International Journal of Technical Research and Applications, Volume2, Special Issue 6 (Nov-Dec 2014), pp.7-10.

[14] Ayoade, J.O. 1993. Introduction to the Tropics. Lagos: Spectrum Books Ltd.

[15] Ogolo, E. O. and Adeyemi, B. 2009. Variations and Trends of Some Meteorological Parameters at Ibadan, Nigeria. The Pacific Journal of Science and Technology 10.2:981-987.

[16] Hegarty, J., Mao, H., and Talbot, R. 2007. Synoptic controls on summertime surface ozone in the northeastern United States, Journal of Geophysical Research, 112, D14306, doi: 10.1029/2006JD008170.

[17] Ding, A. J., Wang, T., Xue, L. K., Gao, J., Stoh, A., Lei, H. C., Jin, D. Z., Ren, Y., Wang, Z. F., Wei, X. L., Qi, Y. B., Liu, J., and Zhang, X. Q. 2009. Transport of north China mid-latitude cyclones: Case study of aircraft measurements in summer 2007, Journal of Geophysical Research, 114, D08304, doi: 10.1029/2008JD011023.

[18] Zhang, Y., Mao, H. T., Ding, A. J., Zhou, D. R., and Fu, C. B. 2013. Impact of synoptic weather patterns on spatio-temporal variation in surface $\mathrm{O}_{3}$ levels in Hong Kong during 19992011, Atmospheric Environment, 73: 41-50.

[19] Ding, A. J, Fu, C. B., Yang, X. Q., Sun, J. N., Petäjä, T., Kerminen, V.M., Wang, T., Xie, Y., Herrmann, E., Zheng, L. F., Nie, W., Liu, Q., Wei, X. L, and Kulmala, M. 2013. Intense atmospheric pollution modifies weather: a case of mixed biomass burning with fossil fuel combustion pollution in eastern China. Atmospheric Chemistry and Physics, 13, 10545-10554.

[20] Onokala, P.C. 2001. Urbanization and Urban transportation problems in Nigeria. Issues in urbanization and urban administration in Nigeria. E.O. Ezeani and N.N. Elekwe. Eds. Enugu: Jamoe Enterprises (Nigeria) Publishers. 168-186.

[21] Adedayo, O. F. and Zubairu, S. N. 2013. An assessment of facilities in motor parks in Minna, Niger State, Nigeria, through post-occupancy evaluation. Management 3.7:360-367.

[22] Anable, J. 2005. Complacent Car Addicts' or 'Aspiring Environmentalists'? Identifying travel behaviour segments using attitude theory. Elsevier Journal of Transport Policy $12: 65-78$ 
[23] Ayeni, M.O.A. 1994. The metropolitan area of Ibadan; its growth and structure. Ibadan Region. M.O Filani, et al. Eds. Nigeria: Rex Charles Publishers. Chapter 7:72-84.

[24] Ajayi, O. et al. 2012. Flood Management in an Urban Setting: A Case Study of Ibadan Metropolis. Nigerian Association of Hydrological Sciences. 65-81. www.unaab.edu.ng.

[25] Titus, S.I. et al. 2010. Refuse disposal practices in three major motor parks in Ibadan municipality, Nigeria. Journal of Public Health and Epidemiology, 2.4:82-86.

[26] World Health Organization 1999. Environmental Health Criteria 213: Carbon Monoxide. 2nd ed. Geneva: World Health Organization.

[27] American Society for Heating Refrigerating and Airconditioning Engineers Incorporated (ASHRAE) 2008. Selecting $\mathrm{CO}_{2}$ : Criteria for Outdoor Air Monitoring. ASHRAE Journal, www.ashrae.org.

[28] Nwadiogbu J.O. et al. 2013. Contributions of vehicular traffic to carbon monoxide emissions in Enugu Metropolis, Nigeria. Archives of Applied Science Research 5.6:189-192.

[29] Asheshi O.O. 2012. Measurement of Traffic Emission in Lafia Metropolis. Journal of Science and Multidisciplinary Research.4:34-46.

[30] Ukpebor, E.E. et al. 2010. Spatial and Diurnal Variations of Carbon Monoxide (CO) Pollution from Motor Vehicles in an Urban Centre. Polish Journal of Environmental Studies 19.4:817-823
[31] Han, X. and Naeher, L.P. 2006. A review of traffic-related air pollution exposure assessment studies in the developing world. Elsevier Environment International 32:106 - 120.

[32] Osuntogun, B.A. and Koku, C.A. 2007. Environmental Impacts of Urban Road Transportation in South-western states of Nigeria. Journal of Applied Sciences 7.16:2356-2360.

[33] Banjoko S.O. et al. 2008. Ambient carbon monoxide and carboxyhaemoglobin levels in Ibadan City, Nigeria: A source of health inequality between developed and developing nations? Journal of Environmental Health Research 1.7. http://www.cieh.org/jehr/jehr3.aspx?id=11484

[34] United States Environmental Protection Agency 1999. Air Quality Criteria for Carbon Monoxide (External Review Draft). National Center for Environmental Assessment, Research Triangle Park, North Carolina: USEPA.

[35] Ndoke, P.N. et al. 2006. Contributions of Vehicular Traffic to Carbon Dioxide Emissions in Kaduna and Abuja, Northern Nigeria. Leonardo Electronic Journal of Practices and Technologies Issue 9:81-90.

[36] Elbayoumi, M. et al. 2014. The effect of seasonal variation on indoor and outdoor carbon monoxide concentrations in Eastern Mediterranean climate. Atmospheric Pollution Research 5:315-324.

[37] Napiorkowska, M. and Tomaszewska, M. 2013. The relationship between Carbon dioxide $\left(\mathrm{CO}_{2}\right)$ /derived/ from SCIAMACHY.ENVISAT-1, meteorological parameters, and vegetation indices - case study of Poland. Geoinformation Issues. 5.1.5:43-56. 